\title{
Problem-Based Learning In Accounting
}

\author{
DuWayne L. Dockter, Slippery Rock University, USA
}

\begin{abstract}
Seasoned educators use an assortment of student-centered methods and tools to enhance their student's learning environment. In respects to methodologies used in accounting, educators have utilized and created new forms of problem-based learning exercises, including case studies, simulations, and other projects, to help students become more active versus passive learners. New instructional technologies have also aided in and supported the development of more efficient and effective instructional and learning environments. As a result, these new innovations have proven very effective in delivering and using educational information. The increased utilization of new technologies, user-friendly software, and advanced forms of delivery systems has allowed teachers to engage more students in the learning process. As a result, these new methodologies and tools have enables the students to access, communicate, and share more information more efficiently and effectively in and out of the classroom. This article helps to review some of the more common methods and tools which are being utilized by seasoned instructors.
\end{abstract}

Keywords: Teaching Methods In Accounting; Accounting Case Studies; Teaching; Learning Platforms; Technologies; Blackboard; Web-CT; Learning Management Systems; Methods; and Accounting

\section{INTRODUCTION}

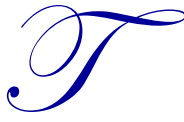

here are many professional speakers who impress us with their credentials, experiences, publications, and research skills. However, it is the seasoned educator utilizing all of these expertises and skills which captures and holds our attention. They use just the perfect blend of teaching methods and techniques to enhance the audience's learning environment and their interaction with an ever-growing database of knowledge. These professional educators have helped us expand our knowledge while making the subject entertaining, challenging, motivating, and understandable in and out of a traditional classroom. In this article, we will explore a few of the methods and techniques used in accounting to help our students learn better.

Before embarking on this journey of exploration, we want to recognize some basis tools which have been used to help individuals learn better and measure their success in learning accounting principles, theories, and concepts. One such standard technique used by many educators is the assignment of short exercises and problems.

Educators in accounting have effectively used short exercises and comprehensive problems over the years to help students learn more and to assess the students' learning attainment. However, short exercises help teachers only to examine the student's conceptual knowledge at a recognition level. If we wish to help the student learn at a higher plane and examine the student's broader set of application skills, then a problem-based learning approach may be a more appropriate and effective tool.

\section{PROBLEM-BASED LEARNING}

\section{Introduction}

In an article written by James Hansen, "Using Problem-Based learning in Accounting", the author demonstrates that problem-based learning can build a better learning environment by elevating the student from a passive to active learning role. In the author's opinion, this is a primary goal allowing the "ultimate attainment of higher cognitive critical, analytical, and problem-solving skills" (James Hansen, 2006, pp. 221-224). 
The goals of 'problem-based learning' are to help students (a) think critically, analyze, and solve complex realworld problems; (b) find, evaluate, and use learning resources; $(c)$ work cooperatively in teams; $(d)$ demonstrate effective communication skills; and (e) use content knowledge and intellectual skills to become continual learners (Duch, Groh, \& Allen, 2001). The 'problem-based learning process' works as follows: Students are presented with a problem (e.g., case, videotape, a research paper); then in groups, they organize their ideas and attempt to define the broad nature of the problem, pose questions, and define and rank learning issues that they do and do not understand. Issues are assigned to each group and individuals within each group choose a particular issue to research and later teach to the other members of their group. Students and the instructor identify resources to research learning issues. The students reconvene, integrating their new knowledge into the context of the problem, and students continue to define new learning issues as they progress through the problem. (Boud \& Feletti, 1997)

Over the past decade, this technique of problem-based learning has been utilized more in undergraduate and graduate education programs where students have already gained a fundamental understanding of accounting concepts and principles and wish to build on this foundation. This has been accomplished with the use of case and simulation studies.

\section{Case Studies}

Since the 1970s, cap-stone classes have used student-centered techniques, such as case studies, to help students apply what they have learned from courses, such as accounting, marketing, management, finance, statistics, and information systems, to arrive at and support a team-based business strategy aimed at reaching the desired case study's learning goals. This technique has been a very effective learning tool and instrumental in helping students attain a higher level of application skills while expanding their knowledge base (Handal, B. Et. al., 2011, pp. 1-17).

As recognized by educators and supported by relevant research, the perception of this learning experience can also help to elevate a student's learning performance (Ferreira \& Santoso, 2008). It was further noted in a research study conducted by Handal that the student learns better by constructing their own knowledge base rather than just having information transmitted to them via a one-way lecture method. In addition, "effective learning occurs in periods of exploration and a cognitive challenge, such as . . 'the' conflict among diverse pieces of information" (Wood, Cobb, \& Yackel, 1991).

\section{Custom-built Case Studies}

In the Washington State University system, problem-based learning is applied in a number of programs as a learning and assessment tool. As an example, Professor Debra Sanders at the WSU, Vancouver campus, builds a final case study for each candidate based on the student's completed course work in tax. Then the student is required to use their previously gained working knowledge and related skills to complete the tax base case study.

The final outcome of the research is a presentation before a graduate committee of the student's findings and recommendations based on the pertinent issues and relevant facts presented in the case. Ultimately, the graduate committee evaluates the student's conclusions and makes a recommendation on how the presentation can be improved as well as if the presentation warrants a pass onto graduation.

At the Tri-Cities campus of Washington State University in Richland, a similar exit assessment must be fulfilled by the MBA students wishing to graduate. Here again, as with the Vancouver campus, students are posed with a case study to help assess their analytical, research, and communication skills in respects to an existing or new business venture. The case studies in this situation are built with the insight of the students' faculty committees and the students. It is an additional assessment of the students' knowledge and application of managerial concepts relevant to the case at hand. As stated on the College of Business website, the students are required to present their conclusions "concisely, persuasively, and professionally" (Washington State University, 2011).

As stated on the College of Business's MBA website, the final presentation on the Tri-Cities campus "is designed to" (Washington State University, 2011): 
- $\quad$ provide an integrative exercise to review and demonstrate a working knowledge of the important theories and concepts form the core courses in the MBA program

- $\quad$ evaluate each student's ability to identify, analyze and interpret data relevant to business problems and issues of organizational context

- $\quad$ allow the committee to assess the student's professional presentation skills

This approach, problem-based learning, is also used in many other learning environments and levels to assess the student's overall knowledge attainment and application/research skills. An example would be in a MBA program. Cases at this level and within this arena must be "analyzed, synthesized, and evaluated"; this is what James Hansen would classify as a level 3 problem-solving-case approach (Hansen, 2006).

A level 3 problem requires analysis, synthesis, or evaluation. It is related to the real world, drawing the student into the problem. Not all of the information needed is given in the problem. . Students need to do some research, discover new material, and make judgments and decisions based on the information learned. The problem may have more than one acceptable answer based on the assumptions the students make. (Hansen, p. 221)

Problem-based learning in the form of tailor-built cases, simulations, and other interactive learning experiences does aid in creating a more positive classroom learning experience, helping students to "remember lessons and key points" better (McKeachie, 1994).

\section{Simulations}

In addition to cases as a form of problem-based learning, "simulations . . . can 'also' be a particularly effective teaching technique by arousing interest, providing a concrete basis for discussion, and by illustrating major principles from the lesson" (Dekkers \& Donatti, 1981). Studies have shown active learning techniques, such as simulations and role-play, to be stronger than traditional methods of instruction in terms of knowledge retention, knowledge application, and motivational outcomes (McKeachie, 1999).

A good example of this technique was illustrated by Rochelle K. Greenberg and Arnold Schneider in the development of a job-order costing simulation (Greenberg and Schneider, 2010). The simulated exercise involved the manufacture of a product through all phases of its production from the purchase of the materials to its final completion. As the authors stated, it was not a superficial overview of job order costing but provided a comprehensive hands-on experience for the students. The hands-on exercise enhanced the students' learning, comprehension, and retention of the process. Further, the follow-up survey at the completion of the simulation showed that the participants thought the realistic exercise helped them learn better and it was considered "fun".

We feel that this is an extremely important differentiation, not only in understanding traditional cost accounting, but in understanding activity-based costing, since the difference between the two methods lies with overhead. This method of teaching job order costing provides the student with a hands-on experience and allows them to actively participate in the learning process. (Greenberg and Schneider, p.39)

\section{Other Learning-Based Projects}

Activity-based investment projects have been used for generations by instructors in investment-related courses where students are asked to invest a sum in securities over a set period of time. In a course, such as intermediate accounting, instructors can use this type of student activity-based project to help students learn how to properly document and record the purchase, sale, and/or transfer of securities in or between one of three balance sheet categories (trading securities, securities available-for-sale, and debt equities held to maturity). The student would also be required to calculate, adjust, and record the appropriate journal entries at the end of each accounting period to reflect the proper fair market value for the trading and available-for-sale securities portfolios. This project was considered by many authors, such as Carter and Jones (2011), as a valuable learning activity because it involves the student in the learning process. 
The purposes of the project are to enhance the students' understanding of the subject of investments and to give them hands-on experience in actually identifying and collecting documentation on stock and bond prices. An additional purpose is to provide an opportunity for the students to prepare work-papers to document the accounting treatment of the simulated transactions. The students are also instructed to incorporate the use of spreadsheets to document their transactions and to summarize their portfolios. The preparation of the work-papers and subsequent instructor comments provide the students with feedback they can utilize both in other school projects and in the workplace. The reward for students participating in this active learning project is a grade of up to 35 points, which represents approximately $5 \%$ of their total course grade. (Carter \& Jones, p. 106)

\section{INSTRUCTIONAL TECHNOLOGIES}

In addition to more student-centered methodologies, the increased utilization of new technologies, userfriendly software, and advanced forms of delivery systems have allowed teachers to engage more students in the learning process. As a result, these tools have enabled the students to access, communicate, and share more information more efficiently and effectively in and out of the classroom. As a result, the learning environment has become a more user-friendly and student centered as demonstrated by Songtao Mo (2011) in his study of the "incorporation of instructional technology in teaching accounting and auditing courses".

The introduction of the instructional technology initiates the shift of the focus of the learning environment from instructors to students." It has helped to "facilitate the interactions between faculty members and students between classes and to enhance the student motivations and engagement in the learning process.

By combining the use of more engaging methodologies and delivery tools, students attain a higher level of learning while being more satisfied with the way in which the information is being presented (Halawi, 20009). These findings were supported by earlier studies by McVay (2008) and Norman (1981). In their studies, it was shown "that a classroom configuration, combined with information technology and a feedback learning processes created a more positive learning environment" (McVay et al, 2008). The creation of the positive learning environment was one of many key factors discussed in the study carried by Handal in exploring the students' perceptions of teaching and learning in the disciplines of business, accounting, and economics. The encouragement of " . . . universal participation in class through enacting a friendly and positive learning environment was an instructional approach highly appreciated by the respondents." (Handal it. Al., 2011)

\section{Using Excel Software as A Learning Tool}

For example, instructors can combine the use of a projection system with an Excel software package to illustrate accounting concepts and principles, such as the allocation of deferred taxes and liabilities over multiple periods. Such a spreadsheet approach has been used at Washington State University, Vancouver, for such an endresult. In addition to being a very effective teaching tool, the students were able to walk away with a practical application template that could be used in their workplace.

A more definitive illustration of using spreadsheets in the classroom and its benefits can be seen in the study conducted by Damian Ringelstein. The article was entitled "An Activity-Based Costing Assessment Task: Using an Excel Spreadsheet" which appeared in the Journal of Business Education \& Scholarship of Teaching.

The aim of using an Excel Spreadsheet as a teaching instrument for an Activity-Based Costing assessment task is to motivate students and to provide them with the opportunity to learn computing skills as well as cost accounting techniques. The assessment task is designed to encapsulate the skills required to create a complex spreadsheet using various commands. .. . The use of computer technology assists students to gain a personal understanding of the issues and to develop a specific set of skills that are useful for management accountants. This task encourages students to learn and develop critical analytical skills. (Ringelstein, p. 25) 


\section{Utilizing Learning Management Systems}

How do learning management systems (platforms), such as Blackboard, Web-CT, and Angel, support a more user-friendly and interactive learning environment?

Multiple subjective and objective-based studies have now shown how the power of technology enhances the learning process and student motivation. In studies conducted by Tinio (2002) and Muianga (2004), the authors in each of their studies demonstrated that technology utilization using platforms improves the quality of the longdistance learning environment. This premise, enhancing the learning environment, was further substantiated by Mo in his study on how the learning process can be enhanced by the use of Blackboard Vista. His study was conducted on an in-class learning environment, an auditing course (Mo, 2011). When applied to e-learning, another study conducted by Muianga also showed how technologies in the form of platforms enabled students to engage actively in the construction of learning rather than being passive recipients of knowledge (Muianga, 2004).

Technology is not merely a simple tool anymore. It "enables flexible, participative and contributionoriented learning" (Collins and Moonen, 2001). The utilization of the platform as an example has also encouraged the incorporation of other multiple media elements that further enable effective and flexible interaction (Henke, 1997; McManus, 1995; \& Mlitwa, 2007).

On the other hand, authors such as Carvalho, Areal and Joaquim, in their study, regarded the use of such platforms as "little more than 'an' electronic document repositories" (Carvalho et al, 2011). Relatively, this is the same conclusion that was reached by another study conducted by Palocsay and Stevens (2008). They didn't see any great advantage to using a platform other that it simplified the creation and grading of assignments; they believed that it was just a simple efficient delivery tool.

There is no argument here that a platform is no more than a tool. However, if designed properly, it is an effective tool by which one's learning environment can be enhanced. This was shown to be the conclusion of a study conducted by Hollenbeck, Mason, and Song (2011). In addition, they identified five fundamental pedagogical design principles as part of their findings which can enhance the student learning environment.

\section{Adopting Other Software and Resources as A Learning Tool}

Today, there are many software packages available from textbook publishers and other vendors which can be used to improve the instruction and learning process; but as stated by Blount and McNeil in their study, the software must be carefully integrated into the curriculum and students must be supported in its use (Blount \& McNeil, 2011). If so, it proves to be a very effective tool.

Like the utilization of platforms as a teaching and learning tool, there are other benefits to integrating software programs into the curriculum. The findings of a survey conducted by Ling and Nawawi of practitioners' computer skill needs for "fresh" graduates include the practical knowledge and skill to use word, spreadsheet, and email programs. The authors further state that tax programs should be integrated into the university's tax course curriculum (Ling and Nawawi, 2010). Of course, this has been done in many universities with the help of vendors making their tax software available for educational use. "In essence, tax educators and practitioners have the same opinion that accounting graduates should possess adequate tax knowledge before joining any accounting tax firms" (Ling and Nawawi, p. 304). "Finally, this study . . provided . . . tax authority, tax educators, and tax practitioners with an insight to make a concerted effort in preparing accounting graduates to survive and thrive in the accounting profession. This could be achieved through designing programs and career paths, in the tax and accounting profession, that are attractive to students." (Ling and Nawawi, p. 314)

\section{SUMMARY}

The combination of new technologies, such as management information systems, and application of student-centered methodologies, such as problem-based learning, have enhanced the student's learning environment in respect to accounting courses taught on the post-secondary level. The contributions of advanced technologies and 
methodologies have been instrumental in promoting student-centered, activity-based learning. As a result, the learning environment has become more efficient and effective, benefitting both the teacher and student.

\section{AUTHOR INFORMATION}

Dr. DuWayne Dockter, CPA, has taught on the secondary and post-secondary levels for over 30 years. Formerly, Dr. Dockter was a full professor of accounting at Concordia University, Portland. He has worked for the IRS as a revenue agent, a staff accountant for small and intermediate accounting firms, and was a visiting assistant professor of accounting at Washington State University, Tri-Cities, djuring the 2011-12 academic year. Dr. Dockter is now employed as an associate professor of accounting at Slippery Rock University. E-mail: ddockter2002@yahoo.com

\section{REFERENCES}

1. Blount, Y. \& McNeil, M. (2011). Fostering Independent Learning and Engagement for Postgraduate Students: Using a Publisher-Supplied Software Program. Journal of Educational Management, 25(4), 390404.

2. Carter, F. L., \& Jones, R. C. (2011, September). Accounting for a Simulated Investment Portfolio: Active Learning Pedagogy in Intermediate Accounting. Academy of Educational Leadership Journal. 15(3), 105117.

3. Carvalho, A.; Areal, N. \& Silva, J. (2011, September). Students' Perceptions of Blackboard and Moodle in a Portuguese University. British Journal of Educational Technology, 42(5), 824-841.

4. Handal, B., Wood, L. \& Muchatuta, M. (2011, June) Student's Expectations of Teaching: the Business, Accounting and Economics Experiences. e-Journal of Business Education \& Scholarship of Teaching, 5(1), 1-17.

5. Greenberg, R. K. \& Schneider, A. Job order Costing: A Simulation and Vehicle for Conceptual Discussion. Academy of Educational Leadership Journal, 14 (3), pp. 39-57.

6. Hansen, J. D. (2006, March - April). Using Problem-Based Learning in Accounting. Journal of Education for Business, 81(4), 221-224.

7. Halawi, L.A., McCarthy, R.V. \& Pires, S. (2009, July - August). An Evaluation of E-Learning on the Basis of Bloom's Taxonomy: An Exploratory Story. Journal of Education for Business, 84(6), 374-380.

8. Hollenbeck, C.R., Mason, C.H., \& Song, J. (2011, August). Enhancing Student Learning in Marketing Courses: An Exploration of Fundamental Principles for Website Platforms. Journal of Marketing Education, 33(2), 171-182.

9. Ling, L., \& Nawawi, N.. (2010). Integrating ICT skills and tax software in tax education. Campus-Wide Information Systems, 27(5), 303-317. DOI: 10.1108/ 10650741011087748

10. McKeachie, W.J. \& Svinicki, M. (2010). Teaching Tips: Strategies, Research, and Theory for college and university teachers. Florence, Ky: Wadsworth Publishing (Cengage Learning).

11. Mlitwa, N. (2004, May). Evaluation of the ICT in higher education (HictE) sub-project 3. The University of the Western Cape, Unpublished.

12. Mlitwa, N. (2007). Technology for teaching and learning in higher education contexts: Activity theory and actor network theory analytical perspectives. International Journal of Education Development Using Information Communication Technology, 3(4)

13. Mo, S. (2011, December). Evidence on Instructional Technology and Student Engagement in an Auditing Course. Academy of Education Leadership Journal, 15(4), 149-158.

14. Muianga, X. (2004). Blended Online and Face-to-Face learning - A Pilot Project in the Faculty of Education at the Eduardo Mondlane University, Mozambique. Presented in the Emerge 2004 Online Conference, University of Cape Town, South Africa.

15. Palocsay, S. \& Stevens, S. P. (2008, July). A Sutdy of the Effectiveness of Web-Based Homework in Teaching Undergraduate Business Statistics. Decision Sciences Journal of Innovative Education, 6(2), 213-232.

16. Ringelstein, D. (2009) An Activity-Based Costing Assessment Task: Using an Excel Spreadsheet. $e$ Journal of Business Education \& Scholarship of Teaching. 3(1), 25-35.

17. Wood, T. (1991, Fall). Change in teaching mathematics: A Case Study. American Educational Research Journal, 28 (3), 587-616. 


\section{Sources:}

\section{Education Fulltext}

Key Search Words

Teaching and Methods and Accounting

Key Search Words

Accounting case studies and teaching

Key Search Words

Learning Platforms and Blackboard

Key Search Words

Accounting and Technologies

2. Sources

ERIC Advanced Search

Education Indexes 
NOTES 